\section{p.30ó 指䓕に成する研究}

611. サッカーのコールキーピンクに旳するこ玻学的 研究

1. 研究の目的 本研究は，サッカーのコールキーピ ングのなかて，特に，シューターの版作を予知する技術

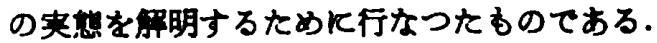

2. 研究の方法 1) 被搶者 東数大サッカー部ゴー

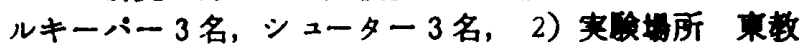
大体育学部. 3) 実駼期日 S.43.9.2 5. 4) 测定種 目 (1)ペナルティーキック, (2) $16 \mathrm{~m}$ ブレースシュート(3) $16 \mathrm{~m} ト$ リブルシュート（本实食）5）即定方法 被険者 (ゴールキーパー) を二分力亚計式接地力計の上K立た せ,シューターの娌きに対応する玫作によつて現われる 現象をビシグラフに記録した．また，被柃者とシュータ

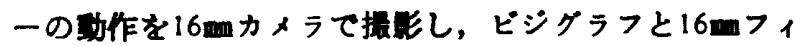
ルム上Kタイムマークを同的䖴した。

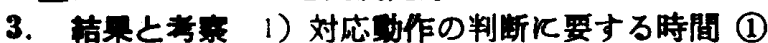
ヘナルティーキックにおける成功率は0\%であり，対応 勏作の判断に0.87秒を要している.これは，判断する時 間が余りにあ短いためと考えられる。 (2)16 16 ブレースシ
ユートKおける成功㭏は20\%であり，対応功作の判断に 1.い秒を要している。これは，判断する時间がやや長く なつたため，对㤁的作がややてきやすくなつたものと考 えられる. (316 $\mathrm{m}$ ドリブルシュートKおける成功率は40 \%でり，対応杪作の判断に1.41秒を要している.これ は，判所する時何がさらに長くなり，より通切な対応怔 作が行なわれたものと巷えられる。

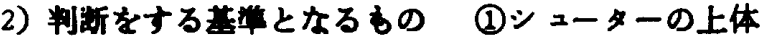
の当き方，(2)シューターのドリブルによるボールの移少 のしかた，(3シュート時におけるシューターの帆足とボ ールとの成保位贯，(4)シュート時に拉けるシューターの 胴足の方向.

\section{6メートルドリプルシュート}

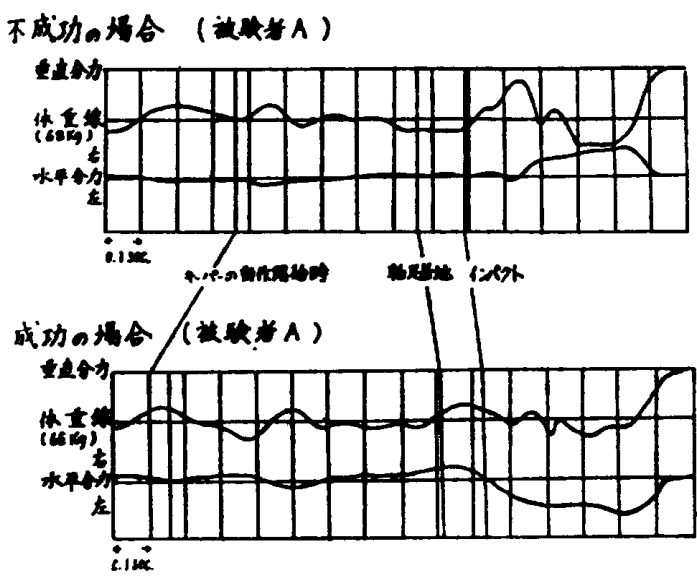

612. サッカータクティクス I

—キックオフ・フリーキック—

東京数育大学○山中 邦夫, 大石三四郎

\begin{tabular}{|c|c|c|}
\hline " & 青井 & 水月，近堂 \\
\hline . & 浅井 & 克妟, 関閏 \\
\hline " & 此田 & 稔，港 \\
\hline
\end{tabular}

昨年はハススのパターンについて発敖したが，今回は， キックオフとフリーキックのパターンを究明すると同時 К, いかにしてそのチームに合つた戦怵をとればよいの か，换言すれば，嗃時飞最高法をとるチームを实現す るにはいかにあるべきかを究明しようとする第 3 のステ ップとした.

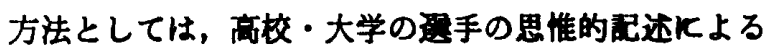
パターンと实蝴察によつて得たものとを，ハスの碂類 别，回数别に整理した。ことに高校と大学との比佼を中

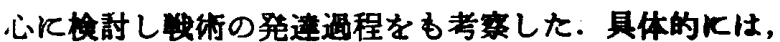
ハスの程類を 8 程類化分類し，またパスの回数について は，キックオフ・フリーキックとも，ボールをプレス としたころから数えて第1回目のハスを1，第2 回目を 2.以下34567とした. 結果は次の 3 点である.

(1) 図式化から，ドリプルの出方の相䢖を見ると，高
校生の方により多くみられ，このことは高校チームと大

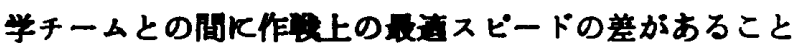
を明的に示するのてある。

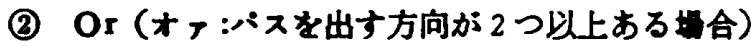
の出方の相远については，大学の方により多く踝められ た. すなわち、これは高校チ一ムと大学チームの技街ま たは作期力の差を示しているるのの।つでると考え ろ. しかし、ゲームの作化あたつていくつのをOr含め ろのが最这てあるのか，更に研究を進める必要がある。

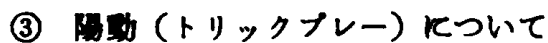

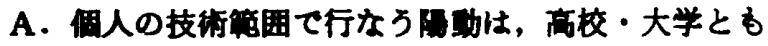
によく見られたか，2〜3人ての略になるといくつかの ハターンは見られたが，竞典的に行なつている增合が少 ないようK思われた。 また，チーム全体ての阿称は，本 研究では全く見られなかつた．以上我↔はチームについ ての最竞法とは何かということについての考実をして

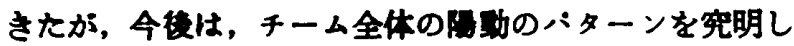
チームKおける传视作とシステム化の問題はいかなる 方法て実現するのか子研究のステップとしたいと思いま 广. 